\title{
Female Freedom and The Neapolitan Novels (Part 2)
}

\author{
Sam Shpall \\ Department of Philosophy, The University of Sydney, Quadrangle Building, A14, NSW 2006 Australia \\ Corresponding author. sam.shpall@sydney.edu.au
}

(Received 4 October 2019; revised 9 February 2021; accepted 20 May 2021; first published online 25 January 2022)

\begin{abstract}
Part 1 of this essay began to develop a philosophical interpretation of The Neapolitan Novels by grounding a vision of the work's moral psychology in the tradition of Italian difference feminism, particularly as it is expressed in the texts of the influential Milan Women's Bookstore Collective. Part 2 advances the interpretive argument by presenting a more detailed literary analysis of the character of Lila Cerullo. After motivating the interest of various aspects of her symbolization by connecting them to important motifs in feminist philosophy and literature, I present evidence of Lila's special status in the work, and the puzzles this status raises. I advance a reading of Lila as a brilliant woman capable of playing the superior role in a hierarchical relationship of entrustment-and of The Neapolitan Novels as a sympathetic yet critical exploration of the viability of such relationships and their connection to female friendship and female freedom. In support of this reading, I give an account of Lila's strange condition of smarginatura ("dissolving margins/boundaries"), the import of her perplexing earthquake speech in which this condition is explicitly addressed, and Elena Greco's troubling reactions.
\end{abstract}

Yes, I hold that male colonization of our imaginations-a calamity as long as we were unable to give shape to our difference-is, today, a strength. We know everything about the male symbol system; they, for the most part, know nothing about ours, above all about how it has been restructured by the blows the world has dealt us. What's more, they are not even curious, indeed they recognize us only from within their system. (Ferrante 2016, 334-35)

\section{A Literary-Philosophical Introduction}

In Part 1 of this essay, I presented some main elements of the moral psychology of the Milan Women's Bookstore Collective, and I began to make the case that familiarity with the Collective's difference feminism is useful background for interpreters of The Neapolitan Novels. I was especially concerned to introduce readers to the relation of affidamento, or "entrustment," and the picture of women's psychology that convinced

(C) The Author(s), 2022. Published by Cambridge University Press. This is an Open Access article, distributed under the terms of the Creative Commons Attribution licence (https://creativecommons.org/licenses/by/4.0/), which permits unrestricted re-use, distribution, and reproduction in any medium, provided the original work is properly cited. 
the Milan Women of this relation's incomparable significance for generating female freedom. Part 2 of the essay advances this general interpretive vision by way of more detailed literary analysis. My focus is on Lila Cerullo's puzzling symbolization and its implications for the ideological framework of the novel. I begin by situating this symbolization within some broader traditions of feminist theory and literary fiction with which Elena Ferrante is more than conversant.

Adriana Cavarero's Relating Narratives: Storytelling and Selfhood (Cavarero 2000) ${ }^{1}$ is one of the most prominent works of modern feminist philosophy in Italian. Ferrante cites it as a major influence, and Cavarero has recently spoken about these connections (Ferrante 2016, 330; Pinto, Milkova, and Cavarero 2020). ${ }^{2}$ In a chapter titled "On the Outskirts of Milan," Cavarero discusses the thought of the Milan Women by retelling a story that the Collective reported in Sexual Difference. Both the original story and Cavarero's invocation are evocative entry points into this essay's themes.

Here is the tale. In the 1970s, two friends named Emilia and Amalia attend, in Milan, la scuola delle 150 ore. (The "150-hour schools" were founded by the Italian left to provide supplementary education for workers and housewives.) Their story appears in the book as a report from Amalia after the premature death of her friend. Amalia relates that, in the early days of their acquaintance, she had judged Emilia boring. Eventually, however, she comes to see how burdened Emilia is ("My life has always been a no"). A desire to help her, as well as friendly affection, emerges. Amalia is, we learn, a "great storyteller." The women grow closer, developing a trusting relationship that centers on the project of autobiographical writing. Emilia feels the need to "organise her thoughts" by writing them down; but she cannot seem to do so to her satisfaction. Reading Amalia's writing and appreciating her gifts of expression, Emilia is moved to tears: she too needs to express herself by telling someone about her life, but she isn't able to "connect any of it up, and so she let herself go." At some point Amalia discovers a solution, which is to write up Emilia's life story herself. "Once I wrote the story of her life, because by then I knew it by heart, and she always carried it in her handbag and read it again and again, overcome by emotion" (Milan Women 1990, 105-6; see also Cavarero 2000, 55-56). The Collective conclude their presentation with a key formulation, which Anglophone readers will know more from Cavarero's discussion (it is her chapter's epigraph) than from Sexual Difference: "The gift of the written story which connects thoughts and saves one from letting herself go is an exquisite image of what we have tried to explain, that is, that in women's struggle, the symbolic revolution-the representation of oneself and of one's fellow women in relation to the world-is fundamental and must come first" (Milan Women 1990, 106).

The echo of this tale in The Neapolitan Novels goes beyond the alliterative tangling of women's names. Emilia's blockage prefigures that of Elena Greco, and of many other women in the narrative, who in their own ways exhibit the condition that sparked the Collective's theorizing. ${ }^{3}$ But it just as clearly evokes the notion of frantumaglia that Ferrante claims to have inherited from her mother (indeed, from her mother's dialect $^{4}$ ) - a notion she repeatedly uses to characterize women's predicament, and which is widely understood to be the central plank in her work's system of metaphors (Milkova 2021, ch. 2). The frantumaglia is a "jumble of fragments," a mental "disquiet," a "mysterious" anguish rooted in the "miscellaneous crowd of things in [a woman's] head, debris in a muddy water of the brain" (Ferrante 2016, 99-100). ${ }^{5}$ This "unstable landscape" disorients in part because it "appears to the I, brutally, as its true and unique inner self" (100). A clear thread thus links the disconnected feelings of Emilia with the most foundational (and "slippery" [Milkova 2013, 95]) element in Ferrante's vision of female suffering. ${ }^{6}$ 
The story offers hints of both diagnosis and cure. It is an organizational talent that Emilia recognizes to be necessary: her life feels shapeless, her ideas lack connectedness, and in despair at her unintegrated personality, she "lets herself go." The Milan Women and Cavarero appear to understand the vital missing link in a similar way. It is the gift of the female storyteller, engaged in a project akin to literary biography: a talented female other "is the only one who can realize such a narration" (Cavarero 2000, 55). The story of Amalia's gift, in other words, links the cure for blockage to entrustment, and entrustment to the practice of storytelling itself. The "symbolic revolution" that is the precondition for female freedom is accomplished via narrative representation of one woman's life by another.

There is a curious feature of the idea, given my argument here. A main ambition of the remainder of this essay will be to present Lila as the primary potential entrustee of Ferrante's fictional world. Yet it is Elena Greco who writes Lila's story-as a response to a distinctive and symbolically rich form of letting go, that is, Lila's enigmatic disappearance. These mixed reverberations of the Amalia-Emilia background only add to its interest. Lila is the extraordinary figure whose original authorization gives Elena the confidence to "go ahead." (In its most succinct materialization: "You're my brilliant friend, you have to be the best of all, boys and girls.") Yet both friends are exceptionally talented women who tell each other's tales in more ways than one. On the surface, Elena's narrative prowess reaches its pinnacle in the novel we are reading, whose aim is, on one charitable conception, to reconstitute the special nature of her friend. Whether this narration ultimately parallels Amalia's generous and liberating intervention depends, however, on the reasons for Elena's storytelling, and on our verdict about the novel's enigmatic conclusion. ${ }^{9}$ Lila is, unlike Emilia, an apparently "unwilling and defiant subject of Elena's narration" (Ricciardi 2021, 103). Lila's "letting go" is intentional: her desire to eliminate the traces of her existence is a response to the traceless vanishing of her beloved child and the other heartbreaking losses she sustains. ${ }^{10}$ Below I will try to articulate more precisely the moral character of Elena's largely illicit biography.

The Amalia-Emilia story is a vivid episode in the narrative of Italian feminism. Whether or not Ferrante had it in mind as she conceived The Neapolitan Novels, it does not seem excessively speculative to suggest that the symbolic associations of this scene, and its roots in the work of the Milan Women, were a part of her artistic formation. Something similar may be said about the following ideas, which introduce the motif of smarginatura (or, in the English translation, dissolving margins/dissolving boundaries) and hence the central argument of this part of the essay. ${ }^{11}$

For the purposes of historical framing, I begin the discussion of smarginatura by making two related points. The first concerns the ubiquity of certain metaphors in prevailing conceptualizations of femininity, and the significance, in certain strands of feminist theory, of oppositional traditions of re-symbolization. The second concerns a connection between Ferrante and Elsa Morante that I hope readers will agree is particularly striking.

There is wide agreement that a key desideratum for any interpretation of The Neapolitan Novels is an illuminating view about the import of Lila's dissolving margins. It is also generally accepted that an important aspect of this theme is its continuity with a longstanding conversation in feminist writing about patriarchal symbolizations of women and femininity. Consider this representative passage from Hélène Cixous:

So, between two houses, between two beds, she is laid, ever caught in her chain of metaphors, metaphors that organize culture... ever her moon to the masculine sun, 
nature to culture, concavity to masculine convexity, matter to form, immobility/inertia to the march of progress, terrain trod by the masculine footstep, vessel ... While man is obviously the active, the upright, the productive .... (Cixous 1981, 44)

Later we will analyze some examples that illustrate Ferrante's interest in gendered celestial images, as well as her interest in reductive conceptualizations of women as passive reproductive "vessels." And no reader can forget the imprint of the "masculine footstep" on the lives of her two protagonists-particularly on the life of Lila Cerullo, who reconceives a man's shoe only to be stepped on more painfully. ${ }^{12}$ However, it is the association of women with the lack of form or integrity that seem to me most essentially engaged by smarginatura and related metaphors (see Wehling-Giorgi 2017, 11 and $2019,74) .{ }^{13}$ Further explicating these connections is one aim of what follows. ${ }^{14}$

I will now note an Italian literary precedent that is especially significant for my account of dissolving margins. I am referring to a pattern of symbolization in the novels of Elsa Morante. It is particularly evident ${ }^{15}$ in her most famous work, La Storia (History: A Novel), whose protagonist Ida Mancuso suffers, in childhood, from a mysterious "unnamed" disease:

In the midst of her games and her childish prattle, she would suddenly fall silent, turn pale, with the impression that the world was spinning and dissolving around her. In reply to her parents' questions, she would utter only a little animal lament, but it was obvious she had already stopped hearing their voices; and a moment later she would put her hands to her head and throat, in a gesture of defense, while her mouth trembled in an incomprehensible murmuring, as if she were having a frightened dialogue with a shadow. (Morante 2000, 29)

The description that follows appears to indicate that Ida is suffering from epileptic seizures. But after a subsequent medical investigation, she is pronounced entirely healthy. Her attacks are merely "temporary manifestations of precocious hysteria"; as the doctor predicts, they disappear as Ida ages (31).

Yet this is not the end of the story. Much later in the novel, the attacks are reborn in her son Useppe. Again, a physician declares that there is no "organic ailment" (446). Unlike Ida's childhood fits, however, Useppe's recur with increasing potency. These "grand mal" (619) attacks afflict the boy mercilessly, and eventually kill him. The death of Useppe-the hero of the book, a "poet of joy and innocence"-cements the tragedy of History. ${ }^{16}$

I want to emphasize one aspect of Useppe's grand mal, critical for an understanding of Morante's work. The apparently physical condition is more fundamentally a marker of Useppe's accurate and indeed visionary moral perception. It represents his personification of goodness (moral innocence, contact with beauty, hopefulness) - and his congenital allergy to the horrors of war, fascism, anti-Semitism, and poverty, horrors that pervade his short life and, it might well be contended, cause his death. ${ }^{17}$ As Lily Tuck says: "The tragedy of war is the actual protagonist of Elsa Morante's novel; it is the grand mal from which Useppe suffers and which affects us all” (Tuck 2008, 194). In sum, the distinctive "disease" of History's hero is in fact a symbol of his heroism.

The same can be said about Lila Cerullo's condition. The heroine of The Neapolitan Novels is a poet of creative destruction. Her smarginatura is in some sense a physiological malady. But it is more fundamentally an expression of her exceptional perceptiveness and strength. ${ }^{18}$ 


\section{Lila and Dissolving Margins}

One worry about the analysis initiated in Part 1 of this work is that it may overstate the parallels between the Elena-Lila relationship and the entrustment relationship as outlined by the Milan Women. I will now attempt to more fully vindicate this connection. First, I systematize the many ways in which Lila is presented as unique-coded as a kind of archetype (or goddess-demon) of female excellence, with powers to remake dominant structures of symbolization and, as a result, individual psychologies. Next, I present a general puzzle about the symbolic content of her perplexing condition of dissolving boundaries, and a suggested resolution. Finally, I offer an extended interpretation of the earthquake speech-among the most interpretively challenging of Lila's many mysterious acts of communication. My interpretation clarifies some of the more subterranean meanings of dissolving margins, integrates these meanings into an overall conception of the work's aims, and solidifies the relevance of the preceding discussion of the Collective's moral psychology.

Various considerations can be offered in support of my claim that Lila is a singular figure in the eyes of Elena, and in the world of the novel, a figure with an intellectualcreative potential characteristic of the brilliant woman entrustee. One theme I discussed in some detail in Part 1: the powerful and permanent inferiority complex of the narrator, with its at times monomaniacal focus on Lila's uncharacterizable greatness. Another I have mentioned in passing: the resume of Lila's extraordinarily varied and unlikely accomplishments, as precocious student, child author, shoemaker, autodidact, artist, political organizer, tech entrepreneur, and historian of Naples. But these facts are obvious. What may be more useful is to recall some of the ways she is described, which are individually notable in the course of reading, yet seldom reproduced in their resounding totality. Here are some key examples, in the order they appear:

Lila is terrible and dazzling (Ferrante 2012-2015, I, 47); she has a dart, a hiss, a lethal bite (I, 48); her thoughts are brilliant, and her gaze is not very childlike or even very human (I, 48); she is a holy warrior (I, 52); a demanding ghost (I, 97); part child, part old woman (I, 118); possessed of a seductive, dangerous essence (I, 143); like a woman born from the head of Zeus $(I, 227)^{19}$; a disrupter, who throws things out of balance (I, 238); a falcon, with extraordinary powers of vision (I, 259); the neighborhood's incarnation of evil (I, 284); a witch of dark arts (I, 291); a good fairy (I, 292); home to an evil force, a poison that murders potential children inside her (20122015, II, 85); capable of seeing the invisible, and of helping others to see it (II, 119); the Devil assuming the figure of a woman (II, 140); a witch-whore (II, 142); an unparalleled commander and inventor (II, 142); a star that might explode, leading everyone to try to grab a fragment (II, 151); a good devil, whose beauty makes men fearful of castration (II, 286); singularly unpredictable (II, 315); too brave, incapable of submitting to reality (2012-2015, III, 36); made badly, especially when it comes to sex (III, 36); someone with the mind that no woman or man has, and the power to change shit into gold (III, 168); an eel who hasn't realized her limitations because she hasn't submitted to a man (III, 168); powerful in a way that makes you want to submit to her, go down on your knees, admit inferiority (III, 210); equipped with an organ for listening that nobody else has (III, 212); ungovernable (2012-2015, IV, 126); a holy warrior who bathes the neighborhood in an avenging light, crushing the demonic camorrists, gaining strength from pregnancy (IV, 153); capable of governing the imagination of others, or setting it free, with just a few words (IV, 169); pursued by a legion of demons (IV, 181); a wielder of magical powers (IV, 210); the highest example of female intelligence (IV, 
236); possessor of a mysterious substance, an energy that comforts, reinforces a purpose, solves problems (IV, 270); worse than the Solaras (IV, 350); a woman with a sort of farsightedness that strikes a creative spark in others (IV, 371); a prisoner inside the inferno of her unsatisfied mind (IV, 395); someone with an intelligence that's gratuitous, irreducible to any purpose or use (IV, 403); a prophetic seer of the future (IV, 444).

These descriptions confirm that Lila is consistently portrayed in a number of strange and seemingly contradictory ways. Here is a systematization. On the one hand, she is characterized as a formidable genius whose spirit is a beacon of liberation. On the other hand, she is represented as an evil force, a troublemaking agent whose darkness has a mystical cast. ${ }^{20}$ The natural resolution of this prima facie tension was intimated in Part 1. Those complicit with patriarchal structures and symbol systems interpret Lila's power demonically. They are right in attributing to her a special character, that is, and wrong in their evaluation of it. ${ }^{21}$

Michele Solara's “tortured but chaste attachment" (Ricciardi 2021, 56) is emblematic. As Lila notes, his obsession with her is "like a superstition," grounded not in sexual attraction but in the perception that she has incomparably productive powers (Ferrante 2012-2015, III, 167). By way of several dramatic monologues, the Camorrist paints his own revealing picture of Lila's gifts. In the speech he gives at Bruno Soccavo's factory, for instance, he offers this rapturous assessment: “she'll change shit into gold for you, she's capable of reorganizing this whole enterprise, taking it to levels you can't even imagine. Why? Because she has the type of mind that normally no woman has but also that not even we men have" (III, 168).

Though he recognizes Lila's greatness, Michele can only reach for objectifying and distorting capitalist metaphors in his attempts to express it. Similarly, his thesis about Lila's sexual difference seems reverential, but quickly transitions to a sexist lament about her insubordination. Lila is, according to Michele, an "eel"-slippery, serpentine, and devilish - who doesn't know her limits. Why? Because, he says, she's never submitted to a man.

The density of expression is even more remarkable in Michele's speech about women and the family:

There's only one other woman who is almost like our mother. . . . You mustn't be offended, Lenù, you're smart, you've gone so far. ... But ... Lina has something alive in her mind that no one else has, something strong, that jumps here and there and nothing can stop it, a thing that not even the doctors can see and that I think not even she knows, even though it's been there since she was born ... for a long time I've wanted to buy this distinctive aspect of her. Yes, buy, there's nothing wrong, buy the way you buy pearls, diamonds. ... (III, 333-34)

We can recognize in Michele's worship of Carmela Solara the flip-side of the Milan Women's concerns about patriarchy's obliteration of the mother. ${ }^{22}$ We may also find his insight into Elena's competitiveness insightful-though it is a manipulative and mean-spirited provocation, as he is rubbing salt in the wounds of the young writer's turbulent homecoming. But the core insight for the argument I'm advancing concerns Michele's vaguely theological interpretation of Lila's mental vivacity, and the reflexively dominating posture of his response to it.

It is no surprise, in other words, that one of the work's chief representatives of patriarchal capitalist oppression conceives of Lila's greatness in terms of an elusive, 
nonrational "aspect," an untraceable feminine vital energy. It is likewise predictable that Michele's recognition of Lila's power is accompanied by a rapacious desire to possess it; and that he sees no difficulty in analogizing the possession of another person's mind to the possession of a precious gemstone. The appropriative impulse here epitomized by Michele is a ubiquitous marker of masculinized social-symbolic structures in The Neapolitan Novels. Lila's rebelliousness must be seen as targeting not only the material dominance of oppressive systems like Michele's-which she eventually dissolves in a number of ways, as we will see-but also, and more fundamentally, the psychology of appropriation that sustains them. ${ }^{23}$

Readers will remember another example of a similar psychic phenomenon. I am referring to Nino's alarming and initially perplexing assertion to Lenù about Lila's makeup: "Lina is brave, even too brave. But she doesn't know how to submit to reality, she's incapable of accepting others and herself . . . she's really made badly: in her mind and in everything, even when it comes to sex" (III, 36). We later learn that to be "made badly" when it comes to sex is, in the first instance, to derive insufficient pleasure from male penetration (III, 375). So the statement encodes multiple insights about Nino's sexism. It is a crude and cold dismissal of his former lover and friend, to her closest friend; a confirmation of Nino's anxious and vindictive masculinity; and a portent of manipulativeness in his dealings with Elena, whom he is here beginning to seduce by preying on her longstanding Lila-insecurity. ${ }^{24}$ Finally, it is an expression whose ambiguity encapsulates two levels of oppressive ideology. Lila is "made badly. . . when it comes to sex" both in the sense that she is uninterested in submitting to the expected sexual regime of penetrative intercourse, and in the sense that she is unwilling to submit to the expectations of her sex-based social roles.

The centrality of this passage supports the claim that Lila is systematically villainized by representatives of patriarchy, who are motivated by an overwhelming desire to possess her-and, failing that, to subordinate her, neutralizing her peculiarly threatening power. $^{25}$ The narrative introduces these dynamics quite early. As Lila reaches puberty, Elena remarks on her friend's "seductive and dangerous essence" (Ferrante 2012-2015, I, 143) and proceeds to narrate two events incited by possessive male desire. The first is the pizza shop incident, in which a "professorial" man in his fifties declares, in front of his own wife and children, that "you have here a girl who will become more beautiful than a Botticelli Venus" (I, 146). His inability to keep this appraisal to himself leads to a violent confrontation with Rino, which further inscribes the scene's "patriarchal optics" (Milkova 2021, 109). The second event is Gigliola's name-day party, which is ruined when "four males, of various ages, each convinced in a different way of his own absolute power, reached out toward the figure of a fourteen-year-old girl" (I, 149-50). Significantly, it is Stefano, Marcello, Enzo, and Pasquale who here try to dance with Lila-and who will continue to treat her as, in her words, "merchandise to barter" (Ferrante 2012-2015, II, 112). The episode ends in tears and promises of future violence.

In short, it is fundamental to the complex magnetism of the fictional character of Lila Cerullo, and hence to the staggering popularity of The Neapolitan Novels, that Lila is perceived within the world of the novel as a powerful force with incommensurably valuable and specifically feminine capacities. ${ }^{26}$ But another feature of Lila's psychology deepens and complicates this story. The condition of smarginatura is for her a lifelong affliction. Most immediately, it is characterized by episodes of frightening dissociation in which the borders of people and objects appear to break or become undone. However, the ease of this phenomenological characterization can obscure 
the thorough yet confusing ways in which "dissolving margins" is positioned at the symbolic core of the novel. ${ }^{27}$

For example, although Lila both observes and experiences the condition throughout her life, we learn in the passage to be discussed below that it is a secret burden, communicated for the first time only (to Elena) in 1980. This detail is easily forgotten. We read about dissolving margins in very early stages of the work, both because Elena is writing the novel late in her life and, significantly, because she has long known about the condition as a result of her invasive examination of Lila's notebooks. ${ }^{28}$ It must be emphasized that the narrator's descriptions of Lila's experiences, and pathologizing of her mind, are infused by a secret knowledge obtained only through a blatant violation of trust-a violation that functions as microcosm for the one Elena commits by writing The Neapolitan Novels. ${ }^{29}$

Further, Lila's dissociative episodes constitute only a handful of the many events in the narrative described with related language. The named instances of dissolving margins appear, in other words, thematically continuous with many other significant events and processes. For example: Elena's childhood "tactile dysfunction," an "enduring malaise" grounded in fears about the distension of bodies, especially her own (Ferrante 2012-2015, I, 57) ${ }^{30}$; Melina's dissociative "attacks of madness," which Lila witnesses with great perturbation (Ferrante 2012-2015, II, 96); the "immolat[ion]" of the "tense, aggressive" Lila as she "disappear[s]" into her role as Stefano's trophy wife (I, 265)_"Cerullo goes toward Caracci, falls into it, is sucked up by it, is dissolved in it" (II, 124); Stefano's transformation during their honeymoon into an "unrecognizable being" and unrepentant rapist ("something in and around him had broken," "the father was cracking his skin, changing his gaze, exploding out of his body") (II, 37, 41); Elena's overshadowing by Lila, characterized as a struggle to "restore clear outlines and depth" to her own life (II, 467); the narrator's self-deceptive enthusiasm about her romantic liberation with Nino, which finds expression in the claim that "Something great is happening that will dissolve the old way of living entirely and I'm part of that dissolution" (Ferrante 2012-2015, III, 418); and Nino's metamorphosis into a more political version of the exploitative father he detests (“The fascists ... aren't always wrong and we should learn to talk to each other") (Ferrante 2012-2015, IV, 228). I discuss the more initially confounding example of Alfonso's identity transformation below.

Similarly, Lila's smarginatura is systematically related to other organizing symbols, making it hard to believe that dissolving margins is significant primarily as an isolated mental disorder. Consider these motifs: disappearing; crossing boundaries; being reduced. Consider these recurring images: liquids and solids; the moon and the sea; the magma of Vesuvius. Consider these objects, whose meanings are sources of intrigue: the exploding copper pot; the reinvented shoes; the doctored photograph in the Solara shoe shop; the erroneously labeled photograph of Elena and Tina in the newspaper. Finally, consider the evident connections between smarginatura and frantumaglia, which as I noted above sits at the core of Ferrante's conception of femininity and her overall artistic vision. ${ }^{31}$

It seems undeniable that an analysis of dissolving margins is critical to an analysis of the work as a whole. ${ }^{32}$ What is this secret, oddly characterized, intensely disruptive condition? What meanings does it express? How do these meanings relate to the overall ambitions of the work? The symbolic content of smarginatura presents a tantalizing puzzle for interpreters. Many readers liken Lila's episodes to panic attacks, with which they share some features. ${ }^{33}$ But to characterize the condition of dissolving boundaries as an anxiety disorder is to dismiss the puzzle rather than solve it. Some critics 
suggest that the condition represents the porousness of the borders of personality (see Bakopoulos 2016; Lee 2016), or, relatedly, Lila's quasi-religious access to facts about the social constitution of the self. ${ }^{34}$ There is something accurate about these ideas, but they must be developed in greater detail if they are to explain the rich significance of this network of symbols.

Above I began to articulate some links between smarginatura and various well-known images from twentieth-century feminist thought. In order to be made compelling, these ideas about Ferrante's preoccupations must be integrated into a more comprehensive reading of her work. In particular, any interpretation of Lila's condition should make it consonant with, and explanatory of, her unique status in the world of the fiction. I will now argue more directly that dissolving boundaries should be principally understood not as a disorder or curse, but as an expression of Lila's visionary abilities. In its most extreme episodes, it involves access to shadowy truths about the foundations of socialsymbolic composition. It involves a unique capacity to grasp the instability of personality, and the concomitant precarity of social life-a precarity particularly evident in the violent transformation of persons that's accomplished by the process of masculinization. It involves, most remarkably, an ability to manipulate and remake persons via mysterious acts of female (that is, subversive) will. That Lila's condition is experienced and presented as a kind of metaphysical affliction is in fact positive evidence for this interpretation. It is consistent with her overall representation as a "good devil"-a prophet of liberation to sympathizers, a master of dark arts to opponents-and a foreseeable consequence of the burdens she faces as a "farsighted" "holy warrior."

\section{The Earthquake Speech}

The earthquake speech is arguably Lila's most vulnerable and revelatory act of communication in The Neapolitan Novels. ${ }^{35}$ It assumes particular significance when we recall that the work is devoted to capturing her purportedly indefinable essence. ${ }^{36}$ Not coincidentally, the speech centers specifically on the phenomenon of dissolving boundaries. ${ }^{37}$ The passage in which it is transmitted is noteworthy for other reasons. Especially important are the complexities of the narrator's response. In this section, I give a close reading that illustrates the main elements of my interpretation. Here is the first key passage:

She used that term: dissolving boundaries. It was on that occasion that she resorted to it for the first time; she struggled to elucidate the meaning, she wanted me to understand what the dissolution of boundaries meant and how much it frightened her. She was still holding my hand tight, breathing hard. She said the outlines of things and people were delicate, that they broke like cotton thread. She whispered that for her it had always been that way, an object lost its edges and poured into another, into a solution of heterogenous materials, a merging and mixing. . . She muttered that she mustn't ever become distracted: if she became distracted real things, which, with their violent, painful contortions, terrified her, would gain the upper hand over the unreal ones, which, with their physical and moral solidity, pacified her; she would be plunged into a sticky, jumbled reality and would never again be able to give sensations clear outlines. A tactile emotion would melt into a visual one, a visual one would melt into an olfactory one, ah, what is the real world, Lenù, nothing, nothing, nothing about which one can say, conclusively: it's like that. And so if she didn't stay alert, if she didn't pay attention to the boundaries, 
the waters would break through, a flood would rise, carrying everything off in clots of menstrual blood, in cancerous polyps, in bits of yellowish fiber. (Ferrante 20122015, IV, 175-76)

Several pieces of information come to us at the outset of this sequence. Lila names her condition, and speaks of it for the first time, only in a moment of terror, prompted by the shaking, cracking disruption of a massive earthquake. We take her confiding in Elena to be significant, and this is confirmed by her reversal of a physical gesture that early in the narrative represented her courage and guiding strength as the girls knocked on Don Achille's door to demand the return of their dolls. ${ }^{38}$ Lila wants to speak. But she also craves, in an unusually vulnerable way, to be understood, supported, and protected. The earthquake speech records an inversion in the typical (though not invariable) psychic dynamics of the friendship.

The passage introduces an intriguing image. In explaining the feeling of the episodes of dissolving, Lila says that the outlines of people and things are delicate, that they break like "cotton thread." 39 The cotton thread evokes feminine domestication, but also the power of feminine narration. ${ }^{40}$ Its rupture in Lila's episodes signals the breakdown of the outlines of objects and especially personalities, which is unsurprisingly experienced as alienating. The image thus links dissolving margins to some of Ferrante's most intriguing and uninhibited descriptions of her literary project-for example, as an exploration of the painful attempts of "daughter-dressmakers" to dissolve the shape of their mothers. ${ }^{41}$

The speech continues with the most challenging sentence in the entire work: "She muttered that she mustn't ever become distracted: if she became distracted real things, which, with their violent, painful contortions, terrified her, would gain the upper hand over the unreal ones, which, with their physical and moral solidity, pacified her; she would be plunged into a sticky, jumbled reality and would never again be able to give sensations clear outlines." I remain perplexed by this passage but will offer a tentative proposal. The real things, which are violent and painful and terrifying, must be related to patriarchy, the (very real) sexist formation of persons and relationships and institutions. ${ }^{42}$ The real things cause dissolving margins-both in the sense of dissolving the moral goodness of people like Stefano and Rino, and in the sense of causing Lila's dissociative episodes, which are ultimately related to her special vision into patriarchy's evils. So the unreal things, which fight against the real ones, must be antipatriarchal.

These unreal things pacify Lila with their physical and moral solidity, their resistance to physical and psychological oppression. But she must be vigilant: the power of the unreal things depends on her focus; if she becomes distracted, the real things will dominate, and she will lose the ability to define herself. What then are these unreal things? The as-yet largely fictitious or underdeveloped antipatriarchal movements, values, symbolic structures, and modes of self-interpretation that Lila glimpses through a glass darkly. In other words, it is communion with the unreal things that comprises Lila's peculiarly heroic substance: her "plus" or "something more"; her vigilant resistance, her avenging light, her unwillingness to submit; her contact with the female symbolic. It is only these unreal things that can give authentic, unsubordinated form to a woman's personality.

Though my overall reading does not depend on the controversial claims of the preceding two paragraphs, which concern only one difficult sentence (a sentence that has received little or no critical attention), it is worth highlighting how the final line of the 
above quotation supports the analysis. If the real things gain the upper hand, Lila says, everything will be washed away-in a "flood" of oppressive femininity. Smarginatura is here associated with the misogynistic conceptualization of the feminine as liquid, as lacking form and substantiality, oozing uncontrollably, melting into watery hysteria. ${ }^{43}$ But Lila's fear is additionally linked to the more specific elimination of women into their procreative capacity, in the images of menstrual blood, cancerous polyps on the reproductive organs, and pieces of yellowish fiber, perhaps from the mucus plug. ("Motherhood seems to me precisely one of those experiences which are ours alone and whose literary truth has yet to be explored" [Ferrante 2016, 347]). That the fear is appropriate could not be doubted by anyone familiar with the events of the narrative so far. The fear is also farsighted. Lila is pregnant with Tina, who will vanish without a trace in a moment of parental distraction. In fact, Lila's "premonition of her daughter's disappearance" (Ricciardi 2021, 136) long predates her speech. When she is having an affair with Nino, she writes in her notebooks of the "sensation of imminent death" (see note 41) and a nightmare of "crossing the stradone just as a truck was coming" and being hit and "dragged away." 44

As she continues speaking, Lila moves to a kind of embryonic self-diagnosis in which she discards her former view that dissolving margins is an episodic condition:

Up to now, she said . . I thought it was a matter of bad moments that came and then passed, like a childhood illness. Do you remember New Year's Eve of 1958, when the Solaras shot at us?. . the trails of the rockets were scraping my brother Rino like files, like rasps, and broke his flesh, caused another, disgusting brother to drip out of him, whom I had to put back inside right away-inside his usual form-or he would turn against me and hurt me... . Do you remember how the night sky of Ischia horrified me? You all said how beautiful it is, but I couldn't. I smelled an odor of rotten eggs, eggs with greenish-yellow yolk inside the white and inside the shell, a hard-boiled egg cracked open. I had in my mouth poisoned egg stars, their light had a white, gummy consistency, it stuck to your teeth, along with the gelatinous black of the sky, I crushed it with disgust, I tasted a crackling of grit. Am I clear? Am I making myself clear? And yet on Ischia I was happy, full of love. But it was no use, my head always finds a chink to peer through, beyond—above, beneath, on the side—-where the fear is. (IV, 176-177)

Her episodes are not merely "bad moments," and this is not a "childhood illness." More generally, dissolving is not only a feature of Lila's subjective phenomenology. In vocalizing her evolving understanding, Lila recalls two foundational experiences. An evaluation of them supports these conclusions.

The first episode is the frightening denouement of the New Year's Eve party, where she observes the adolescent Rino beginning to dissolve. The boy who was once a loving and supportive brother begins to transform before her eyes-into a violent copycat of the Solaras who seems destined to harm her. ("It is in fact the male body that displays the first symptoms of dissolving boundaries" [de Rogatis 2019, 205]). Lila's repulsion is insightful. Rino's incorporation into the misogynistic and crony-capitalist order of the Camorra will eventuate in horror for Lila, her family, and Rino himself. The second experience is of an evening conversation at Maronti beach on the island of Ischia. Nino and Elena are extolling the beauty of the sky, indulging in the exuberance of adolescent romanticism. But though Lila is in love with Nino, and in some sense happy, she is incapable of aping these common sentiments. Again, her disorientation and 
estrangement are perceptive. She inchoately grasps the rottenness of heterosexual romantic love for women and cannot be complicit in its adoring symbolization. She is transfixed not by the beauty of the heavens, but by the rotten smell of victimized "egg stars": women whose light and generative potential is appropriated and spoiled. ${ }^{45}$ In both cases, the content of Lila's alarming perceptual experiences encodes an unusual prescience, distinguishing her from everyone else in a way that highlights her symbolic role-as a kind of otherworldly rebel against prevailing norms and the ideas and associations that sustain them.

After recalling these memories, Lila moves to a more startling, mystifying confession:

But was I sick? Did I really have a murmur in my heart? No. The only problem has always been the disquiet of my mind. I can't stop it, I always have to do, redo, cover, uncover, reinforce, and then suddenly undo, break. Take Alfonso, he's always made me nervous, ever since he was a boy, I've felt that the cotton thread that held him together was about to break. And Michele? Michele thought he was who knows what, and yet all I had to do was find his boundary line and pull, oh, oh, oh, I broke it, I broke his cotton thread and tangled it with Alfonso's, male material inside male material, the fabric that I weave by day is unravelled by night, the head finds a way. (Ferrante 2012-2015, IV, 177-78)

This passage again repudiates illness-centered interpretations of her condition. It again demonstrates why it is misleading to say that the phenomenon is primarily something that happens to Lila. It again reveals why it is more accurate to say that dissolving is a feature of reality about which Lila has special observational powers. And, more extraordinary, it suggests that Lila is herself a dissolver of boundaries. Indeed, she is so actively and powerfully disposed that she can't help doing it. The "disquiet" of her mind makes it inevitable that she will continually reinvent, uncover, break, dissolve the world around her-and its inhabitants. ${ }^{46}$

I pause to summarize one main conclusion of the argument so far. In giving shape to this special aspect of Lila, Ferrante employs interconnected metaphors that are staples of patriarchal symbolization, metaphors that express, in normal contexts, damaging associations of femininity with insubstantiality, hypersensitivity, liquidity, passivity, the lack of integrity and authority. ${ }^{47}$ But she reinvents Lila's condition as a powerful mode of imagination and narrative agency. The connection between this reconstructive account of smarginatura and the larger themes we have been pursuing is a virtue of the present interpretation.

As she recounts two important examples of her ability as dissolver, Lila mixes them together in a way that can be deceiving. We should bear in mind that these examples leave very different emotional residues. ${ }^{48}$ First, she notes that Alfonso has always seemed to her in danger of losing his form. Alfonso's official personality has concealed a repressed sexuality and/or gender identity whose nature Lila has long intuited. What Lila does not mention is that Alfonso credits her with the acceptance and development of his authentic being, with his evolution into an integrated person. His characterization of Lila's influence: she "forced" him to "take a little of her," they got "mixed up," and this allowed him to become who he is. ${ }^{49}$ Alfonso's descriptions of his liberation, and his evident reverence, reinforce the positioning of Lila as a borderline religious figure, a secular priestess whose experiments in dissolution and reconstitution call to mind transubstantiation as much as the Collective's hypotheses about the circulation of the female plus. As Elena says after Alfonso dies, "She must have looked at him as at a mirror 
and seen herself in him and had wanted to draw out of his body a part of herself" (Ferrante 2012-2015, IV, 305). ${ }^{50}$

Second, Lila refers to the creative destruction she has unleashed on Michele Solara, who now "runs after the shadow of [Lila's] shadow" (IV, 167). The arch-macho mob boss is carrying on a secret affair with Alfonso, which endangers his reputation and the security of the Solara organization. Her "tangling" with Alfonso becomes, in other words, part of Lila's strategy to humiliate and weaken the Camorra. Sadly, she is right to feel anxious about this potent use of her powers. Alfonso's brutalization at the hands of the Solaras is a catastrophic blow to Lila and her lifelong rebellion. It should be seen as part and parcel of the annihilation of her progeny which completes the tragedy of her life. ${ }^{51}$ The monologue concludes with a sequence of self-deprecation and a plea for help:

But it's not much use, the terror remains, it's always in the crack between one normal thing and the other.... I can't manage to solidify myself around any goodwill. Maestra Oliviero was right, I'm bad. I don't even know how to keep friendship alive. You're kind, Lenù, you've always had a lot of patience. ... So please, if I insult you, if I say ugly things to you, stop up your ears, I don't want to do it and yet I do. Please, please, don't leave me, or I'll fall in. (Ferrante 2012-2015, IV, 178)

Lila's self-criticism contains hyperbolic inaccuracies. She claims to be incapable of keeping friendship alive-in speaking to her intimate friend of several decades, who venerates her even when hating her and wishing her dead. She claims to know of her own moral depravity, agreeing with the old rebukes of Maestra Oliviero, a teacher and would-be mentor who treats the adolescent Lila with despicable resentment and immaturity. ${ }^{52}$ She claims that Elena is full of "patience," notwithstanding her habit of abandoning Lila for months and even years at a time, often for reasons that are at best questionable, and at worst vindictive and self-deceptive. There are a few moments of weakness in which the heroine of The Neapolitan Novels succumbs to the unflattering interpretations of others, particularly other women. The earthquake speech is one of these moments. Especially illustrative here is the (surely misguided) idea that Lila cannot "solidify" herself around any goodwill. The formulation appropriates both content and imagery from her critics. ${ }^{53}$ As I will now show, various features of the narrator's complicit response support this line of thought.

\section{Elena Greco}

Lila's failures of insight indicate her extreme distress and uncharacteristic fragility in the earthquake's aftermath. But they also underscore the significance of her supplication. On a handful of occasions, Lila turns to Lenù for a kind of support nobody else can provide. ${ }^{54}$ In these moments the hierarchy between them appears to reverse. Since I think it is useful to understand the end of Lila's speech as a kind of forthright entrustment plea, I find it interesting to wonder about the possibility of reciprocal entrustment, especially in relations of friendship between talented contemporaries. This possibility is critical for any fuller elaboration and critical evaluation of the Milan Women's ideas. ${ }^{55}$

Setting that issue to the side, it is pivotal for an interpretation of the women's friendship, and thus the Quartet as a whole, to understand the impact of Lila's plea on the psychology of the narrator. Here is the heart of Elena's response: 
But, even now as I pondered the wave of Lila's distraught words, I felt that in me fear could not put down roots, and even the lava, the fiery stream of melting matter that I imagined inside the earthly globe, and the fear it provoked in me, settled in my mind in orderly sentences, in harmonious images, became a pavement of black stones like the street of Naples, a pavement where I was always and no matter what the center. I gave myself weight, in other words, I knew how to do that, whatever happened... I I would remain firm, I was the needle of the compass that stays fixed while the lead traces circles around it. Lila on the other hand-it seemed clear to me now, and it made me proud, it calmed me, touched me-struggled to feel stable... . However much she always dominated all of us and had imposed and was still imposing a way of being, on pain of her resentment and her fury, she perceived herself as a liquid and all her efforts were, in the end, directed only at containing herself. (Ferrante 2012-2015, IV, 179)

This coda is one of the saddest passages in a constantly devastating book. In explaining how it crystallizes Elena's moral stagnation, I will tie up several threads of the preceding discussion.

I have argued that Lila's earthquake speech is a moment of unsurpassed thematic significance. Nevertheless, the narrator's reaction is just as important, and much easier to ignore. It is distinguished by self-absorption that produces deeply distorted vision. One sentiment overpowers all others: Lenù is proud. The object of her pride is not the special power of her friend. It is not the strength that the burden of this special power has required from her. It is not even the fact that she, Elena Greco, is the lone recipient of this remarkable woman's trust. Her pride's object is herself. The distortions of pride are evident in moral misapprehension-and in the flimsy mental transitions that result from it. For Elena, the episode's main takeaway is an unjustified conclusion about her own superiority as an autonomous subject. ${ }^{56}$

The narrator's effusive use of symbols confirms this depressing conclusion. Two facts are especially salient. First, Elena begins with a flowery description of an existential fear that seems plucked from a far less accomplished novel than the one she is composing ("the fiery stream of melting matter that I imagined inside the earthly globe”). In fact, she is unconsciously plagiarizing Lila's more memorable use of this Vesuvian imagery in a cutting putdown - a putdown whose formulation seems, in retrospect, a poem of foretelling. In response to Elena's boasting about her classical high school, which she couches as a theoretical worry about theology class and the definition of the Holy Spirit, Lila launches into her most extended and adversarial oration of volume I:

You still waste time with those things, Lenù? We are floating over a ball of fire. The part that has cooled floats on the lava. On that part we construct the buildings, the bridges, and the streets, and every so often the lava comes out of Vesuvius or causes an earthquake that destroys everything. There are microbes everywhere that make us sick and die. There are wars. There is a poverty that makes us all cruel. Every second something might happen that will cause you such suffering that you'll never have enough tears. And what are you doing? A theology course in which you struggle to understand what the Holy Spirit is? Forget it, it was the Devil who invented the world, not the Father, the Son, and the Holy Spirit. (Ferrante 2012-2015, I, 261) 
There is irony in the impotence of this literary thievery. The moral shortcomings of Elena's competitive narcissism are exposed by her inadvertent and self-undermining reliance on Lila's gifts.

Second, the narrator crams her response with masculine-coded metaphors of subjectivity and strength, applied fawningly to her own person. She is "orderly" and "harmonious"; she is the "center" of a "pavement of black stones" that resembles the streets of Naples (described by Ferrante 2016, 220 as a "male city"); she gives herself "weight," whether or not anyone helps her to do it; she is "firm," like the stable "needle of the compass," whereas Lila is merely "a liquid" who struggles to "feel stable," who must devote "all her efforts" to the project of "containing herself." Elsewhere Elena says that "no one knew better than I did what it meant to make your own head masculine so that it would be accepted by the culture of men; I had done it, I was doing it" (Ferrante 2012-2015, III, 281). Alas, in spite of this general feminist consciousness, Lenù fails to appreciate how internalized misogyny imbues her reaction to Lila's confession and her retrospective analysis of Lila's condition. ${ }^{57}$

Setting aside my claim that we are here observing Elena's distressing complicity with oppressive systems of symbolization, her final conclusion is a remarkable non sequitur. Elena's enduring anxieties and feelings of blockage are conditioned by her psychologically primal contact with the exceptional powers and achievements of her friend. If all of Lila's efforts were devoted to the project of containing herself, then our narrator's lifelong inferiority complex could have no object. ${ }^{58}$

The narrative presents a fantasy of self-realization that is rooted in self-deception. It is destined to be short-lived. Lenù's tranquil confidence and self-esteem depend not on a recognition of her own independent virtues - substantial, unique, and varied-but on an obscure sort of triumph over her closest friend, whose status as unparalleled female agent has just been, unbeknownst to our narrator (or at least to her conscious narrating self) definitively confirmed. The illusion of overcoming is undermined by her exhibitionistic expressions and flimsy flights of reasoning, exemplifying a principal arc of the narrative, which is the arc of Elena Greco's unhappiness. One of the main aims of The Neapolitan Novels is to show us a brilliant woman, bursting with potential, who (with a bit of luck and help from her friend(s)) exceeds all expectations-but is nonetheless corrupted by her desire to be the best. Elena's anxieties about inferiority will return. Her amazing successes, her fame, her crossing of boundaries will do little to dispel her bitterness. She will end up in bourgeois solitude, consumed by doubts about life's meaning, ambivalent about her relationships, longing for Lila to reappear. ${ }^{59}$

The psychic trajectory of the narrator can be seen as the culmination of the ideas about female freedom that I have been pursuing. In relating The Neapolitan Novels to the work of the Milan Women, I have focused primarily on the puzzle of Lila's special status and her related condition of dissolving margins. But the evolution of Elena Greco is just as richly suggestive. The narrator never makes peace with Lila's brilliance, though she always depends on it. This is the crux of her struggle. ${ }^{60}$ It is also the core of a stimulating extension of the model of female relationships proposed by the Collective, in which the confrontation with female excellence is both the source of female freedom and a chief obstacle in its path. Ferrante may have something like this in mind when she says that "the drive toward equality has put us in a competition with men but also with each other, multiplying the ferocity of [our] relations" and that "competition between women is good only if it does not prevail” (Ferrante 2016, 222 and 359).

I conclude this essay with a lingering question, whose answer completes my interpretive argument about Elena Greco's ambiguous development. The question: Is 
Lila's own competitiveness morally akin to the narrator's? As an adult she refuses to read Elena's writing, dismissing its importance; on the rare occasions that Lila does engage with Elena's mature work, she subjects it to searing criticism. Many readers see this as an uncharitable expression of resentment at Elena's opportunities and achievements. Lila does have a longstanding sourness that makes up part of her response to Elena's literary efforts. ${ }^{61}$ She is, more generally, disposed to reactive emotional brutality. Yet an additional fact is relevant to her perspective on Elena's work. Her criticism expresses an anguished disappointment with Elena's literary career, a career that is grounded in steadily accelerating tendencies of artistic objectification.

The pinnacle is the story of the narrator's story On Friendship. Elena publishes this work in 2007, toward the end of the novel's events. Again, it contravenes a promise not to write, but this time in the starkest way: it describes Tina's disappearance in detail, with an "exaggerated" depiction of Lila and Elena's childhood loss of the dolls (their "pretend daughters") that is intended to "accentuat[e] the trauma of the loss" of Lila's "real daughter" (Ferrante 2012-2015, IV, 465). Here is an essential report:

It was very well received, and it still sells well today; teachers recommend it to students as summer reading. But I hate it. Just two years ago, when Gigliola's body was found in the gardens... Lila had made me promise that I would never write about her. Instead, here, I had done it, and I had done it in the most direct way. For a few months I believed that I had written my best book, and my fame as a writer took off again. . . . But already by the end of 2007 . . . when I went to Feltrinelli in Piazza dei Martiri to present On Friendship, I suddenly felt ashamed and was afraid of seeing Lila in the audience. ... When I returned to the hotel, a bit more confident, I tried to telephone her. . . . She didn't answer me, she hasn't answered me since (my italics). (IV, 339)

In using loved ones and their stories as a means to fame and self-esteem, Elena reveals a further complicity with the oppressive forces she has ostensibly joined Lila in fighting. Lila is characterized by the gratuitousness of her intelligence ${ }^{62}$-that is, by her refusal to submit her intellectual-creative gifts to any debasing use-and by her social-symbolic project of loving reconstitution, her holy war for the soul of the neighborhood (and its children, women, workers, and gender-bending men). Elena appears increasingly defined in opposition, as an instrumentalizer whose brilliance is channeled as a selfcentered tool of flight. ${ }^{63}$ The tragedy of the tetralogy has many faces, but the appropriative literary gaze of Elena Greco is one of its most unsettling. ${ }^{64}$

Having revealed these facts at the end of her narrative, Elena begins her epilogue with a verdict on the work she is finishing. Her reflections concern two subjects: Lila Cerullo, and the accomplishments of Elena Greco.

I can't believe it myself. I've finished this story that I thought would never end. I finished it and patiently reread it not so much to improve the quality of the writing as to find out if there are even a few lines where it's possible to trace the evidence that Lila entered my text and decided to contribute to writing it. But I have had to acknowledge that all these pages are mine alone.... (IV, 469)

Readers must judge the veracity of such claims to independence, and by extension the measure of Elena Ferrante's distance from Elena Greco. They are not without hints. ${ }^{65}$ 
The epic narrative of The Neapolitan Novels seems as if it will end with this detached opining about authorship. Then Lila inserts herself, producing an enigmatic coda of her own devising. The sending of the dolls is a rich and compelling bookend whose meanings I cannot adequately characterize here. ${ }^{66}$ However, we can be confident that in this reappearance, Lila reasserts her claim to being, like her childhood novel The Blue Fairy, the "secret heart," the animating spirit, of Elena's literary work. Ferrante herself suggests this interpretation. Asked about her sympathies, she says: "I love Lila a lot; that is, I love the way in which Elena tells her story and the way in which Lila tells her own story through her friend." 67

\section{Conclusion of Part 2}

Part 1 of this essay presented some central ideas from the tradition of Italian difference feminism. I hoped to motivate philosophical interest in the work of the Milan Women's Bookstore Collective, in particular; and I endeavored to show that familiarity with this work could contribute to interpretation and appreciation of The Neapolitan Novels. Part 2 has continued the story. I have not claimed to offer a comprehensive interpretation of this colossus of a novel, and in presenting my analyses I have tried to register my indebtedness to some of the highly sophisticated work on Ferrante being developed by literary critics. That said, I believe the discussion here-of Lila's characterization, smarginatura, the earthquake speech, and Elena's reactions-has succeeded in its ultimate goal of confirming the relevance of the Collective's feminist theory and practice. This intellectual background helps to contextualize various puzzles about Ferrante's narrative choices. It helps to explain the meanings embedded in her famous and murky system of governing metaphors. It adds texture to provocative questions about the narrator's unreliability. And it motivates compelling hypotheses about the novelist's distinctive perspective on the moral psychology of women's liberation.

Acknowledgments. For helpful discussions of this material, I would like to thank Giorgia Alù, Jonathan Baskin, David Bronstein, David Collins, Helen Deutsch, Nate Gadd, Moira Gatens, Yarran Hominh, Rebekah Johnston, Sherry Marks, Dalia Nassar, Luke Russell, William Shpall, Caroline West, Andrea Westlund, Daniel Wodak, Lorenzo Zucca, and two reviewers for Hypatia. I am especially grateful to Taylor Markey and Natalie Stoljar for their support of the project, to Lily Patchett for her insightful and enthusiastic research assistance, and to Benedetta Magoga for her help with translations from Italian.

\section{Notes}

1 See Roncalli 2015, 66 for reservations about the English translation of the title Tu che mi guardi, tu che mi racconti.

2 Several scholars writing about the Quartet discuss Cavarero's work. See especially de Rogatis 2019, 43; Zarour Zarzar 2019; Di Martino 2021; Milkova 2021, 127; and Ricciardi 2021, 103.

3 See Lenù's description of the budding feminist consciousness of the women's groups: "although we were all women... we struggled to understand what a woman was. Our every move or thought or conversation or dream, once analyzed in depth, seemed not to belong to us" (Ferrante 2012-2015, III, 351).

4 It would be just as satisfying if the story of this term's genesis were a fiction. "The mother tongue in which we have learned to speak and to think is, in effect, the father tongue. There is no mother tongue, since there is no language of women" (Cavarero 1993, 197). "[F]eeling literally in pieces could be traced back to that sort of original fragmentation that is bringing into the world-coming into the world. I mean feeling oneself a mother at the price of getting rid of a living fragment of one's own body; I mean feeling oneself a daughter as a fragment of a whole and incomparable body" (Ferrante 2016, 224). For more on translating (or not translating) the word frantumaglia, see Milkova 2021, 18. 
5 Tellingly, Elena describes the confusion and instability of her love for Nino as reducing her to "a pile of debris" (Ferrante 2012-2015, IV, 100).

6 "The feeling of a radical blockage of the word corresponds also to the viewpoint of many women, for whom putting into words and lying seem almost, and often are, the same thing" (Muraro 2018, 30).

7 See Di Martino 2021, for example, 57: “As Ferrante suggests, her rewriting of myths ultimately entails seeking a 'thread of orientation' that will enable her heroines to 'govern [their] getting lost' after they have recognized themselves as an 'aerial and aquatic mass of debris' whose life is 'the storehouse of time without the orderliness of a history, a story."

8 "In its most crystallized form, the person to whom one entrusts oneself is the woman (or women) who supports one's desire for freedom, who says: 'Go ahead'” (Zerilli 2004, 76). She is referring to an episode recounted by the Milan Women, which I cannot summarize here. Their narration of the episode ends in this way: "In any case, it was a fundamental experience, an experience in which the stuff of past life was transformed into writing. It gave H. D. the feeling that she had a poetic vocation, together with the certainty that all this was possible because of the woman who was beside her and who, at the decisive moment, said to her: 'Go ahead'” (Milan Women 1990, 34).

9 Recall that the narrator's ambivalent motives are emphasized from the outset: reconstituting Lila's essence is both literary homage and an attempt to "win." See Santovetti 2018, 533.

10 "The disappearance of women should be interpreted not only as giving up the fight against the violence of the world but also as clear rejection" (Ferrante 2016, 327).

11 Smarginare is a typographical term for cutting the edges of a page, which is reinvented in Ferrante's poetics. See note 27 for a word about Ann Goldstein's translation of smarginatura. Stiliana Milkova notes that the neologism is Lila's (Milkova 2021, 38)- "The term isn't mine, she [Lila] always used it" (Ferrante 2012-2015, I, 89) - and that Goldstein omits the rest of this sentence- "forzando il significato comune della parola" (forcing or breaking open the common meaning of the word). For especially important discussions, see de Rogatis 2019, ch. 3, and Milkova 2021, ch. 2. As Tiziana de Rogatis says, smarginatura "governs The Neapolitan Novels both formally and thematically" (de Rogatis 2019, 15).

12 The end of "Adolescence" (and of volume I) is, for Lila, her betrothed's betrayal of a promise. She has been clear: "Marcello Solara must absolutely not set foot in my wedding" (Ferrante 2012-2015, I, 311). He arrives, of course. What's more, he is wearing her shoes: "They were Cerullo shoes for men. Not the model for sale, not the ones with the gilded pin. Marcello had on his feet the shoes bought earlier by Stefano, her husband. It was the pair she had made with Rino, making and unmaking them for months, ruining her hands" (I, 331).

13 For one point of reference, compare Naomi Schor: "Few claims Irigaray has made for feminine specificity have aroused more virulent accusations of essentialism than her 'outrageous' claim that woman enjoys a special relationship with the fluid" (Schor 1994, 51). As Schor notes, though the association is "appropriated from the repertory of misogyny" (52), Irigaray means to valorize female "fluidity" by sympathetically reconceiving not just women's sexuality but women's consciousness as well.

14 To anticipate: we should think of Lila's project as akin to the symbolic revaluation recommended by Luce Irigaray, among others: "I am trying, as I have already indicated, to go back through the masculine imaginary, to interpret the way it has reduced us to silence, to muteness or mimicry, and I am attempting, from that starting-point and at the same time, to (re)discover a possible space for the feminine imaginary" (Irigaray 1985, 164). For one example of such revaluation, consider Irigaray's take on the vessel metaphor (Irigaray 1993, for example, 51). For discussion of Ferrante's visual and tactile metaphors, respectively, see Milkova 2016 and Zarour Zarzar 2019.

15 See also Morante's Aracoeli (Morante 2009, especially 254). Several scholars have discussed connections between Morante and Ferrante. See, for example, Wehling-Giorgi 2017 and Milkova 2021, 116.

16 "Useppe is the poet of joy and innocence. He is close to nature, to animals and birds. The novel is full of dogs and cats who have been anthropomorphized into compassionate companions and whom Useppe understands and can speak to. He recites his poems to Nino's dog, Bella (a maremmana), and she answers him back" (Tuck 2008, 184).

17 Useppe's final, lethal fit is precipitated by a brutal denial of love. Davide Segre, a surrogate older brother (and a Jew, like Morante), has slipped into depression, an addiction to heroin, and a world-historical pessimism that results in hermetic misanthropy. In his final days, Davide brutally turns Useppe away: "Clear out, you ugly fool, you and your lousy dog!" The child is crushed. One description jumps out in the present context: "Useppe had exactly the same sensation as if an earthquake had been released from the center of the universe." The scene is devastating. See Morante 2000, 694. 
18 Ferrante cites Morante as an "unsurpassable" inspiration (Ferrante 2016, 250). Compare Bojar 2018, 74 for some parallels between Morante and Lila, and de Rogatis 2019, 21 for some parallels between History and the Quartet.

19 Like Athena, that is-a warrior goddess destined to be even wiser and more powerful than her father. 20 See Alessia Ricciardi's extraordinary discussion of the Faust epigraph, where it is claimed that the sharp-tongued Lila is a contemporary feminist Mephistopheles (Ricciardi 2021, 19-25). (Ricciardi also argues that Ferrante's translation of the epigraph into Italian gives us important clues about her identity.) I am happy to admit that this treatment addresses the concern voiced in Part 1 about the relative lack of attention given to the epigraph. I think that my claims in the text are useful elaborations of the Lila-as-devil idea. For another note about Lila's "supernatural" and "demonic" intellectual gifts, see Bojar 2018, 77.

21 'The 'too' of a woman produces violent male reactions and, in addition, the enmity of other women, who every day are obliged to fight among themselves for the crumbs left by men" (Ferrante 2019, 30). See also Van Ness 2016, 298, who describes Lila as "a violator of taboo whose boldness blazes a trail for Elena." 22 Compare the "Myths" section of Beauvoir 2011: "But if woman is posited as the Praying Mantis, the Mandrake or the Demon, then the mind reels to discover in her the Muse, the Goddess Mother and Beatrice as well" (Beauvoir 2011, 276). See also Adrienne Rich: "Throughout patriarchal mythology, dreamsymbolism, theology, language two ideas flow side by side: one, that the female body is impure, corrupt, the site of discharges, bleedings, dangerous to masculinity, a source of moral and physical contamination, 'the devil's gateway.' On the other hand, as mother the woman is beneficent, sacred, pure, asexual, nourishing; and the physical potential for motherhood-that same body with its bleedings and mysteries-is her single destiny and justification in life... In order to maintain such notions, each in its contradictory purity, the masculine imagination has had to divide women, to see us, and force us to see ourselves, as polarized into good or evil, fertile or barren, pure or impure" (Rich 1976, 34).

23 As I noted in Part 1, my interpretation of the connection between Lila's rebellious power and her special persecution is continuous with the analysis of misogyny's patterns of victimization offered by Kate Manne: "They ['down-girl' moves] put women in their place when they seem to have 'ideas beyond their station"" (Manne 2018, 69).

24 See Ricciardi 2021, 124 for a discussion of Elena's "inescapable sense of Lila's superiority."

25 "Afraid of woman, legislators organise her oppression" (Beauvoir 2011, 91). Nino's eventual political career involves a betrayal of his origins that parallels his betrayal of Lila.

26 On "Ferrante fever," compare Karen Bojar 2018, who is speaking for many when she says that "I cannot recall any books that I have read in my adult life which have affected me as powerfully as Elena Ferrante's novels" (Bojar 2018, 13).

27 There are substantial issues in translating the term smarginatura. Ann Goldstein discusses her choice of "dissolving margins/boundaries" in Harvey 2016. For a critical take that accords with much of the account offered here, see Ricciardi 2021, 43-52. The Italian verb smarginare is used primarily in specialized professional contexts, and scholars writing about Ferrante give subtly different characterizations of its meanings. Its primary use refers to trimming the margins of printed pages in book production (remember Lila's editorial incursions into several of Elena's texts, including The Neapolitan Novels itself); it may also evoke the cropping of photographs (remember Lila's doctored self-portrait in the Solara's shoe shop, which Milkova diagnoses as "the ultimate usurpation of male crative power" [Milkova 2021, 123]). As Ricciardi claims, "['dissolving margins'] normalizes the strangeness with which smarginatura strikes a native speaker's ear, thus sacrificing the incantatory power that it acquires in Ferrante's writing" (Ricciardi 2021, 44). Interestingly, Goldstein seems ambivalent about her translation (Langstone 2016): "A word like smarginatura-people like to talk about that word. I never remember how I ended up translating that, I think it's 'dissolving boundaries.' But if I had known that that was going to come up again in book three or four with the earthquake where she really talks about it at much greater length, I might have chosen a different phrase."

28 Compare Fernando's assault on the young Lila (Ferrante 2012-2015, I, 90) and the rooftop New Year's Eve party (I, 89, 176).

29 See Lila's unequivocal demand, to which Elena acquiesces: "write, if you want, write about Gigliola, about whoever you want. But about me no, don't you dare, promise" (Ferrante 2012-2015, III, 28-29). As I discuss in the final section, Elena's betrayal is far worse than either of the women could have at this point imagined.

30 "Lila may christen this incredible experience, but her friend lived through it first, and only lacked the courage to name it" (de Rogatis 2019, 88). 
31 "Smarginatura is a concrete manifestation of frantumaglia as a terrifying experience of losing boundaries and corporeal dissolution" (Milkova 2021, 15). Merve Emre also explicitly connects these two notions, which she says register the "senselessness of our inner lives, and the impossibility of representing that senselessness through language" (Emre 2020, 222). For extended discussion, see de Rogatis 2019, ch. 3, and Milkova 2021, ch. 2. My ambition now will be to show that some such formulations miss a crucial, positive dimension of Lila's condition.

32 Grace Bullaro and Stephanie Love claim that the concept of smarginatura is "arguably the thematic and conceptual platform of Ferrante's oeuvre" (Bullaro and Love 2016, 5).

33 See Lucamante 2018, 36, who says that Lila "comes across-in Elena's narration-as a hysterical woman constantly on the brink of a nervous breakdown (or smarginatura)."

34 "[Lila] feels that she is losing her solid outlines, she is in a way, blurring her boundaries and melting into her surroundings-metaphorically losing her identity" (De Luca 2017). See also Shulevitz 2015, who refers to Lila's episodes as "something like mystical visions" and emphasizes their synesthetic qualities.

35 A similarly resonant episode is Lila's re-composition, with Elena's assistance, of her wedding photo for the Solara shoe shop. See the excellent discussions of Wehling-Giorgi 2019, 75 and Milkova 2021, $123-25$. 36 This is true, on my reading, at two levels of analysis. First, one of the narrator's main ambitions is to tell the story of the Lila-Elena friendship, to "win" (by achieving insightful novelistic characterization), and to thereby force Lila to "reappear." (Does she reappear? The ambiguity is sublime. See my later remarks concerning the final episode of the novel.) Second, one of the author's main ambitions is to construct Lila as the center of her work: to invent a powerful, unique woman whose symbolic characterization is essential to the conception of female freedom being valorized.

37 For Victor Zarour Zarzar, the earthquake is "the instance in which smarginatura shifts from the affective to the geological." I'll now argue that there is, in one sense, no such instance: smarginatura is a mental-affective phenomenon, but for Lila it is invariably prompted by acute vision into troubling features of external reality (Zarour Zarzar 2019, 195).

38 See the opening of "Childhood: The Story of Don Achille": "We climbed slowly toward the greatest of our terrors at that time, we went to expose ourselves to fear and interrogate it. At the fourth flight Lila did something unexpected. She stopped to wait for me, and when I reached her she gave me her hand. This gesture changed everything between us forever" (Ferrante 2012-2015, I, 29). I noted in Part 1 a connection between this important passage and Ferrante's remarks in an interview about both Luisa Muraro's work and a special memory of her mother. See Rogatis 2019, 141-42 and Milkova 2021, 41. Also relevant is the scene of Elena's visit to the sausage factory. The newly minted university graduate is excited to tell Lila that she has written a novel and that it will be published. Though Lila is presumably envious of Lenù's freedom given her profound subordination in the factory, she expresses her pride wordlessly: "she took my hand and kissed it, first on the back, then on the palm" (Ferrante 2012-2015, II, 462). For an analysis of many additional features of this astonishing scene, see Riciardi 2021, 93-94.

39 Compare the image of "cotton wool" in an earlier passage: "She said that from the day of her marriage until those days on Ischia she had been, without realizing it, on the point of dying. She described minutely a sensation of imminent death: lack of energy, lethargy, a strong pressure in the middle of her head, as if between the brain and the skull there was an air bubble that was continually expanding, the impression that everything was moving in a hurry to leave, that the speed of every movement of persons and things was excessive and hit her, wounded her, caused her physical pain in her stomach and in her eyes. She said that all this was accompanied by a dulling of the senses, as if they had been wrapped in cotton wool, and her wounds came not from the real world but from a hollow space between her body and the mass of cotton wool in which she felt she was wrapped" (Ferrante 2012-2015, II, 295). Notice that although much of this description evokes the experience of migraine, it would be unsatisfying to offer a purely medical diagnosis of the symbolization. The "hollow space" between Lila's body and the cotton wool suggests, to me, the ill-fittingness of social constructions of femininity, which dull her potential and lead to the lethargy of blockage. This interpretation is supported by Ferrante's likely allusion to Virginia Woolf's essay "A Sketch of the Past" (Woolf 1985), which famously uses the image of cotton wool to represent moments of "non-being."

40 "Throughout the ages, the aptitude for the particular makes [women] into excellent narrators. Cornered in weaving rooms, like Penelope, they have, since ancient times, woven plots with the thread of storytelling" (Cavarero 2000, 54). Thanks to an anonymous reviewer for this reference. See discussion at Di Martino 2021, 57 and Milkova 2021, 163. 
41 "I've tried to describe the painful, more or less unhappy journey of the fabric-let's say-with which even we ourselves, the daughter-dressmakers, make the mother's body shapeless" (Ferrante 2016, 219). Compare Ferrante 2019, 73: "A secret cord that can't be cut binds us to the bodies of our mothers."

42 "[T] $]$ he characters who undergo the annihilating loss of form that so alarms Lila are all men" (Ricciardi 2021, 51). Though this may be overstated, it supports my contention that the violent, terrifying reality Lila describes is the reality of patriarchal socialization. See Ferrante 2016, 222: "The sexual difference, repressed in the name of a disguised egalitarianism, is in danger of being pushed back into old roles that we ourselves have slightly touched up or eliminated out of opportunism. The patriarchy, in short-I say this in angerseems to me more alive than ever. It holds the planet firmly in its hands and whenever it can it insists even more than before on making women cannon fodder."

43 "Can it be that in the West, in our time, the female body has been constructed not only as a lack or absence but. . . as a leaking, uncontrollable, seeping liquid; as formless flow; . . as lacking selfcontainment ... a formlessness that engulfs all form, a disorder that threatens all order?" (Grosz 1994, 203). 44 Because I regard this first portion of the speech as especially difficult, and because detailed discussions of it are rare, it is worth briefly noting another natural interpretive hypothesis. Some readers see Lila's realunreal distinction in a more traditionally mystical light. Lila, they say, sees beyond the veil of perception, into the Heraclitean flux of formless reality-or its mental correlate, the frantumaglia. Compare Chihaya 2020, 141: "In the earthquake-the moment in which the frantumaglia gushes through the boundary between internal and external, undoing formal control in the mind and in the very real world-Lila reveals the secret of her multiplicity. It lies, of course, in her perpetual proximity to the unformed chaos that undergirds everything." I do not deny these associations. But the interpretations need not compete. And the system of gendered references in this passage cries out for analysis. Thanks to David Bronstein and an anonymous reviewer for discussion of these ideas.

45 The narrator compares Lila to a star in a revealing passage: "I was afraid that, whatever she wore, her beauty would explode like a star and everyone would be eager to grab a fragment of it" (Ferrante 20122015, II, 151), whereas the night sky and its gelatinous blackness recall several recurring symbols of oppressive masculinity: darkness, hardness, mass, solidity, materiality. Compare a passage of traumatic repression in which Elena tells herself, and her readers, that she is unfazed by her sexual encounters with Donato (II, 294): "That for the first time a tiny part of another body had entered it [my body] seemed to me irrelevant: the nighttime mass of Sarratore communicated to me nothing except a sensation of alienness, and it was a relief that it had vanished like a storm that never arrives." It is no accident that Nino's romantic poetics on the beach remind us, when we look back from the vantage point of 1980, of the love poems of his father Donato. For a challenging discussion of Elena's feelings about Donato, see Ricciardi 2021, 35-41, for example, 41: "Notwithstanding Elena's claims, the story of Donato and Elena is in fact a chronicle of repetition, of successive acts of compliance with her aggressor's desires."

46 "No wonder Alfonso undergoes his transformation thanks to Lila, the character who most catalyzes the dissolving of boundaries" (de Rogatis 2019, 155).

47 It is reasonable to wonder whether the Milan Women's metaphor of blockage might be similarly damaging. They would presumably respond by noting that the cited patriarchal metaphors purportedly trace "natural" or "essential" features of female being, whereas the metaphor of blockage diagnoses a contingent mismatch between free female being and female social reality. Though I cannot discuss the connections, it is worth saying that the feature of Ferrante's project I am exploring here is related to some of the best recent feminist discussions of the importance of metaphor. See Fraser 2018.

48 And though she does not mention him in this monologue, Enzo's transformation from rock-throwing dominator to chaste and loving sidekick is also relevant. See Elena's description of Enzo as Lila's "subordinate": "It was she who moved things, who made and unmade. So, to exaggerate just slightly, the situation in the neighbourhood seemed in a short time to have become the following: you learned to be like Marcello and Michele or to be like Lila" (Ferrante 2012-2015, IV, 129-30). Pasquale agrees: "There is no woman like you, you throw yourself into life with a force that, if we all had it, the world would have changed a long time ago" (Ferrante 2012-2015, III, 115).

49 " $[\mathrm{T}]$ he one who was cheated was me, cheated by myself, and if Lina hadn't helped me I would have died cheated.... Even as a child ... I knew I wasn't what the others thought but not what I thought, either. I said to myself: I'm another thing, a thing that is hidden in the veins, it has no name and waits. But I didn't know what that thing was and especially I didn't know how it could be me, until Lila forced me-I don't know how to say it-to take a little of her. You know what she's like, she said: start here and see what happens; so 
we were mixed up - it was a lot of fun-and now I'm not what I was and I'm not Lila, either, but another person who is slowly defining himself' (Ferrante 2012-2015, IV, 211). My view is that Alfonso's account motivates a further interesting hypothesis. He has taken a piece of Lila (and, by extension, Elena) in another symbolically significant way: he has taken their childhood dolls. There is no definitive textual evidence for this claim, but there are suggestive details at Ferrante 2012-2015, I, 66: “Alfo, did you take it?"-and at IV, 472: "and maybe he [Don Achille] had imagined that it was his son Alfonso who stole them, and so had compensated us with money to buy new ones."

50 Elena adds that this is the "complete opposite" of what she had narrated in her second book, whose theme is the mythology of man's invention of woman. Ferrante has said that Alfonso is her favorite male character in the Quartet (Ferrante 2016, 345).

51 Lila's intelligence and moral wisdom is often characterized as a refusal to submit to use (or instrumentalizing appropriation). Does she use Alfonso here in her battle for the soul of the neighborhood? Does she feel guilty, as if she has betrayed not only Alfonso but also herself-and does this help to explain the psychological contours of her eventual disappearance? Lenù at first endorses something like this pessimistic conclusion: "Lila's fault, I thought in the heat of the moment: with her mania for forcing others by mixing everything up, she overwhelmed him" (Ferrante 2012-2015, IV, 304). But she quickly recants, acknowledging that she has not fully understood the character of Lila and Alfonso's relationship. I prefer to interpret Lila's guidance of Alfonso as he does-as a generous and loving instance of entrustment. Though she does attempt to manipulate Michele, that manipulation may have also been for the good of all involved. It is the Solara family who bears responsibility for Alfonso's death and Michele's renewed repression.

52 See especially Ferrante 2012-2015, I, 208, where Oliviero treats Elena's mother as if she were "disposable"; I, 308, where Oliviero pretends not to know Lila, who has brought her a wedding invitation; and the brutal remarks at I, 277: “The beauty of mind that Cerullo had from childhood didn't find an outlet, Greco, and it has all ended up in her face, in her breasts, in her thighs, in her ass, places where it soon fades and it will be as if she never had it." Elena's response: "I felt that I was her most successful student and went away relieved." Bojar observes: "Elena has absorbed Maestra Oliviero's values on a deeper level, valuing above all the pursuit of individual advancement over solidarity" (Bojar 2018, 124).

53 Just as her language recalls Emilia's predicament, Lila's inability to solidify herself is like Emilia's inability to connect her mental fragments, and Lila's fear of falling into the cracks is like Emilia's fear of letting herself go. 54 Compare Elena's ability to convince Lila that she should marry Stefano (Ferrante 2012-2015, I, 310), and her counsel during Lila's breakdown after her fight with Bruno in the factory. Elena's chivalric selfrepresentation on the latter occasion is telling: "I feel like the knight in an ancient romance as, wrapped in his shining armor, after performing a thousand astonishing feats throughout the world, he meets a ragged, starving herdsman, who, never leaving his pasture, subdues and controls horrible beasts with his bare hands, and with prodigious courage" (Ferrante 2012-2015, III, 172).

55 See Ricciardi 2021, 133 for the claim that Lila and Elena's entrustment relation is reciprocal.

56 This seems to me a convincing and textured example of Iris Murdoch's contention that love (or ideal love) requires an overcoming of ego-distortions (Murdoch 2001). Incidentally, the comparative context here also provides support for Bernard Williams's amusing claim that what philosophers "lay before themselves as an alternative to literature will not be life, but bad literature” (Williams 1993, 13). Murdoch's example of $\mathrm{M}$ and $\mathrm{D}$ in The Sovereignty of Good is, for me, less compelling than the example being discussed here.

57 For a milder version of some of these thoughts, see de Rogatis 2019, 76: "Elena insists on pointing out her own stability during Lila's breakdown after the earthquake of $1980 \ldots$. . But she is merely being defensive. Well before her friend, Elena has experienced smarginatura . . though she doesn't know it or want to define it." 58 The narrator's symbols in this passage are particularly representative of some of the connections I was at pains to frame in my introductory remarks. Ferrante's revaluation of these images via Lenù's unreliable narration will be, for some readers, more comprehensible and enlightening than similar revaluations in the work of writers like Irigaray. Compare Irigaray: "Thus if every psychic economy is organized around the phallus (or Phallus), we may ask what this primacy owes to a teleology of reabsorption of fluid in solidified form" (Irigaray 1985, 110).

59 Though Ferrante valorizes female achievement, she represents Elena's anxiously competitive desire as pathologically masculine, analogizing her striving for fame and genius to Nino's self-promotion in the search for status and power-and to the Faustian pact invoked by the epigraph. "Elena's narrative undermines the celebratory view of work as a means to happiness . . especially when we consider the symbolic correspondences between her story and its antecedents in German literature" (Ricciardi 2021, 79). 
60 Compare Bojar 2018, 78-80 on Elena's envy, impostor syndrome, and failure to acknowledge Lila's influence. As I hope to have shown, the narrator oscillates between these states and more loving reverence. 61 See the first such incident, when a reluctant Lila edits Elena's essay for Nino's journal: "You're very clever, of course they always give you ten. ... I don't want to read anything else that you write ... it hurts me" (Ferrante 2012-2015, I, 300). Elena soon realizes that Lila's modifications have transformed the essay: "On the page was exactly what I had written, but it was clearer, more immediate. The erasures, the transpositions, the small additions, and, in some way, her handwriting itself gave me the impression that I had escaped from myself and now was running a hundred paces ahead with an energy and also a harmony that the person left behind didn't know she had." The loving artistic synergy attained here is matched only in a few moments of Elena's life. Compare the doctoring of the photo, with its "magnificent hours of play, of invention, of freedom, such as we hadn't experienced together perhaps since childhood" (Ferrante 2012-2015, II, 120), and the writing of the Solara article, which appears to Elena to have "descended from Heaven" into Lila's computer (Ferrante 2012-2015, IV, 312). The communion of these fleeting moments contrasts starkly with the isolation that is the ultimate consequence of Elena's life as an author. See the outstanding treatment in Milkova 2021, ch. 4 of the "play of shared creation" as a major theme. Compare Chihaya et al.2020,3 on their project of "collective criticism," and its relationship to Elena's observation that "the solitude of women's minds is regrettable" (Ferrante 2012-2015, III, 354). I discuss the project of collective criticism in Shpall 2021.

62 "She possessed intelligence and didn't put it to use but, rather, wasted it, like a great lady for whom all the riches of the world are merely a sign of vulgarity" (Ferrante 2012-2015, IV, 403). See Ricciardi 2021, 82 on Lila's admiration for Pietro, who loves study for its own sake, and who lacks the narcissism of worldly ambition.

63 "I felt strong, no longer a victim of my origins but capable of dominating them..." (Ferrante 20122015, IV, 260). "Elena the writer is not immune from the risk of either colonizing or instrumentally appropriating..." (di Martino 2021, 62).

64 Critical opinions about the significance of On Friendship diverge. Milkova claims that this book is Elena's masterpiece (Milkova 2021, 145). De Rogatis claims that in writing this book, Elena "lashes out against Lila" because she is "racked with envy, reticent, insecure" (de Rogatis 2019, 53). For perspectives related to the one I am defending, see Santovetti 2018, 539: "So Elena has ransacked . . . the life of her friend in order to provide material for her writing. . . she got rich. . . making a spectacle of her life"; and Loofbourow 2020, 246: "Lenù's betrayal goes far beyond reading and discarding Lina's notebooks. Her decision to reconstruct her friend, to explain her, to reveal her in public is an act of violence, especially toward someone who fantasizes about disappearing."

65 "I had always overestimated her, nothing memorable would emerge from her-something that reassured me and yet truly upset me. I loved Lila. I wanted her to last. But I wanted it to be I who made her last. I thought it was my task. I was convinced that she herself, as a girl, had assigned it to me" (Ferrante 2012-2015, IV, 463). See di Martino 2021, 60: "Hence, readers cannot help but distrust the unreliable Elena, whose own internal conflict between the desire for interrelationality and the need for autonomy the tetralogy repeatedly foregrounds, when towards the conclusion she claims that, in spite of her friend's ongoing influence on her writing, 'Lila is not in these words."'

66 Milkova 2021, 85-86 proposes a variety of interpretations. See Van Ness 2016 for the idea that the childhood rejection of the dolls is an antimaternal act that expresses Lila's precocious feminist impulses; and de Rogatis 2019 for the idea that Ferrante's daughters engage in symbolic matricide on the road to repairing their relations with their mother. Perhaps the "restitution" of Lila's final gesture is a return to the play of shared creation and mutual entrustment (see similar ideas in di Martino 2021, 70 and Milkova 2021, 129). I should emphasize that my pessimistic take on Elena's literary motivations, particularly in On Friendship, need not and does not extend wholesale to her project in the masterwork we actually get to read. Throughout this essay I have observed that the narrator's composition of the Quartet is animated by both loving reverence for Lila and more problematic desires to possess and surpass her.

67 Ferrante 2016, 360. See also 243, where she contrasts Nino and Lila: "Lila's traits instead seem to me the only possible pathway for those who want to be an active part of this world without submitting to it."

\section{References}

Bakopoulos, Natalie. 2016. We are always us: The boundaries of Elena Ferrante. Michigan Quarterly Review 55 (3): 396-419.

Beauvoir, Simone de. 2011. The second sex. Trans. Constance Borde and Sheila Malovany-Chevallier. New York: Vintage Books. 
Bojar, Karen. 2018. In search of Elena Ferrante: The novels and the question of authorship. Jefferson, N.C.: McFarland.

Bullaro, Grace Russo, and Stephanie V. Love. 2016. Introduction: Beyond the margins: "Ferrante vever" and Italian female writing. In The works of Elena Ferrante: Reconfiguring the margins, ed. Grace Russo Bellaro and Stephanie V. Love. New York: Palgrave MacMillan.

Cavarero, Adriana. 1993. Towards a theory of sexual difference. In The lonely mirror: Italian perspectives on feminist theory, ed. Sandra Kemp and Paola Bono. London: Routledge.

Cavarero, Adriana. 2000. Relating narratives: Storytelling and selfhood. Trans. Paul A. Kottman. London: Routledge.

Chihaya, Sarah. 2020. Unform. In The Ferrante letters: An experiment in collective criticism, ed. Sarah Chihaya, Merve Emre, Katherine Hill, and Jill Richards. New York: Columbia University Press.

Chihaya, Sarah, Merve Emre, Katherine Hill, and Jill Richards. 2020. Introduction: Collective criticism. In The Ferrante letters: An experiment in collective criticism, ed. Sarah Chihaya, Merve Emre, Katherine Hill, and Jill Richards. New York: Columbia University Press.

Cixous, Hélène. 1981. Castration or decapitation? Signs 7 (1): 41-55.

de Luca, Mariagrazia. 2017. Elena Ferrante's “smarginatura” and the identity of women: An interview with Grace Russo Bullaro. La Voce de New York. https://www.lavocedinewyork.com/en/arts/2017/04/13/elenaferrantes-smarginatura-and-the-identity-of-women/

de Rogatis, Tiziana. 2019. Elena Ferrante's key words. New York: Europa Editions.

di Martino, Loredana. 2021. Addressing each other's eyes directly: From Adriana Cavarero's "Relating Narratives" to Elena Ferrante's intersectional ethics of narrative relations. Gender/sexuality/Italy 7. https://www.gendersexualityitaly.com/5-addressing-each-others-eyes-directly/

Emre, Merve. 2020. The cage of authorship. In The Ferrante letters: An experiment in collective criticism, ed. Sarah Chihaya, Merve Emre, Katherine Hill, and Jill Richards. New York: Columbia University Press.

Ferrante, Elena. 2012-2015 (I-IV). The Neapolitan novels (L'amica geniale). Trans. Ann Goldstein. Melbourne: Text Publishing.

Ferrante, Elena. 2016. Frantumaglia: A writer's journey. Trans. Ann Goldstein. New York: Europa Editions. Ferrante, Elena. 2019. Incidental inventions. Trans. Ann Goldstein. New York: Europa Editions.

Fraser, Rachel. 2018. The ethics of metaphor. Ethics 128 (728-55).

Grosz, Elizabeth. 1994. Volatile bodies: Toward a corporeal feminism. St. Leonards, NSW: Allen and Unwin. Harvey, Melinda. 2016. Ann Goldstein on translating Elena Ferrante and the inner workings of The New Yorker. The Lifted Brow 31.

Irigaray, Luce. 1985. The "mechanics" of fluids. In This sex which is not one. Trans. Catherine Porter, with Carolyn Burke. Ithaca, N.Y.: Cornell University Press.

Irigaray, Luce. 1993. An ethics of sexual difference. Trans. Carolyn Burke and Gillian C. Gill. Ithaca, N.Y.: Cornell University Press.

Lee, Alison. 2016. Feminine identity and female friendships in the "Neapolitan" novels of Elena Ferrante. British Journal of Psychotherapy 32 (4): 491-501.

Loofbourow, Lili. 2020. Guest Letter. In The Ferrante letters: An experiment in collective criticism, ed. Sarah Chihaya, Merve Emre, Katherine Hill, and Jill Richards. New York: Columbia University Press.

Lucamante, Stefania. 2018. Undoing feminism: The Neapolitan novels of Elena Ferrante. Italica 95 (1): 31-49.

Manne, Kate. 2018. Down girl: The logic of misogyny. Oxford: Oxford University Press.

Milan Women's Bookstore Collective. 1990. Sexual difference: A theory of social-symbolic practice. Trans. Patricia Cicogna and Teresa de Lauretis. Bloomington: Indiana University Press.

Milkova, Stiliana. 2013. Mothers, daughters, dolls: On disgust in Elena Ferrante's La figlia oscura. Italian Culture 31: 91-109.

Milkova, Stiliana. 2016. Elena Ferrante's visual poetics: Ekphrasis in Troubling Love, My Brilliant Friend, and The Story of a New Name. In The works of Elena Ferrante: Reconfiguring the margins, ed. Grace Russo Bellaro and Stephanie V. Love. New York: Palgrave MacMillan.

Milkova, Stiliana. 2021. Elena Ferrante as world literature. London: Bloomsbury.

Morante, Elsa. 2000. History: A novel. Trans. William Weaver. Hanover, N.H.: Steerforth Press.

Morante, Elsa. 2009. Aracoeli. Trans. William Weaver. Rochester, N.Y.: Open Letter.

Muraro, Luisa. 2018. The symbolic order of the mother. Trans. Francesca Novello. Albany: SUNY Press.

Murdoch, Iris. 2001. The sovereignty of good. London and New York: Routledge Classics. 
Pinto, Isabella, Stiliana Milkova, and Adriana Cavarero. 2020. Storytelling philosophy and self writingpreliminary notes on Elena Ferrante: An interview with Adriana Cavarero. Narrative 28 (2): 236-49.

Ricciardi, Alessia. 2021. Finding Ferrante: Authorship and the politics of world literature. New York: Columbia University Press.

Rich, Adrienne. 1976. Of woman born: Motherhood as experience and institution. London: Virago.

Roncalli, Elvira. 2015. Narrating the self through the other: On the thought of Adriana Cavarero. In Contemporary Italian political philosophy, ed. Antonio Calcagno. Albany: SUNY Press.

Santovetti, Olivia. 2018. Melodrama or metafiction? Elena Ferrante's Neapolitan novels. The Modern Language Review 113 (3): 527-45.

Schor, Naomi. 1994. This essentialism which is not one: Coming to grips with Irigaray. In The essential difference, ed. Naomi Schor and Elizabeth Weed. Bloomington: Indiana University Press.

Shpall, Sam. 2021. Writing together: Elena Ferrante and the challenge of collective criticism. ABC Religion and Ethics. https://www.abc.net.au/religion/samuel-shpall-elena-ferrante-and-the-challenge-of-collective$\mathrm{cr} / 13319666$

Shulevitz, Judith. 2015. The hypnotic genius of Elena Ferrante. The Atlantic, October.

Tuck, Lily. 2008. Woman of Rome: A life of Elsa Morante. New York: Harper Perennial.

Van Ness, Emma. 2016. Dixit mater: The significance of the maternal voice in Ferrante's Neapolitan novels. In The works of Elena Ferrante: Reconfiguring the margins, ed. Grace Russo Bellaro and Stephanie V. Love. New York: Palgrave MacMillan.

Wehling-Giorgi, Katrin. 2017. Playing with the maternal body: Violence, mutilation, and the emergence of the female subject in Ferrante's novels. California Italian Studies 7 (1): 1-15.

Wehling-Giorgi, Katrin. 2019. Rethinking constructs of maternity in the novels of Elena Ferrante and Alice Sebold. Women: A Cultural Review 30 (1): 66-83.

Williams, Bernard. 1993. Shame and necessity. Berkeley: University of California Press.

Woolf, Virginia. 1985. A sketch of the past. Moments of Being, ed. Jeanne Schulkind. London: The Hogarth Press.

Zarour Zarzar, Victor Xavier. 2019. Bumping into the novelistic scaffolding: Narrative structure in Elena Ferrante's Neapolitan novels. Contemporary Women's Writing 13 (2): 186-202.

Zerilli, Linda M. G. 2004. Refiguring rights through the political practice of sexual difference. Differences: A Journal of Feminist Cultural Studies 15 (2): 54-90.

Sam Shpall is Senior Lecturer in the Department of Philosophy at the University of Sydney. He writes on a range of topics in ethics, social philosophy, and the philosophy of art. sam.shpall@sydney.edu.au

Cite this article: Shpall S (2022). Female Freedom and The Neapolitan Novels (Part 2). Hypatia 37, 111-135. https://doi.org/10.1017/hyp.2021.80 